\title{
OSTEO-CARTILAGIOUS CHORISTOMA OF TONSIL
}

\author{
K. Shoba', Harikumar², K. Srinivasan³ ${ }^{3}$ K. Deepak Raj ${ }^{4}$
}

\section{HOW TO CITE THIS ARTICLE:}

K. Shoba, Harikumar, K. Srinivasan, K. Deepak Raj. "Osteo-Cartilagious Choristoma of Tonsil". Journal of Evolution of Medical and Dental Sciences 2014; Vol. 3, Issue 33, August 07; Page: 8916-8917,

DOI: $10.14260 /$ jemds/2014/3143

ABSTRACT: Choristoma is presence of histologically normal tissue or cells in abnormal location. Osteo-cartilaginous choristoma is very rare in tonsil. Our intensive search did not show any results on osteo-cartilaginous choristoma of tonsil, hence this case presentation.

KEYWORDS: Tonsil, cartilage, bone, choristoma.

INTRODUCTION: Choristoma is presence of histologically normal tissue or cells in abnormal location. Osteo-cartilaginous choristoma is very rare in tonsil. Our intensive search did not show any results on osteo-cartilaginous choristoma of tonsil.

CASE REPORT: A 23years old male patient presented with history of recurrent attacks of sore throat. Throat examination showed multiple white spots on both the tonsils. Patient was provisionally diagnosed to have keratosis tonsil. Patient was counseled about the benign nature of the disease and antiseptic gargles were advised.

As the patient was not convinced, we had to proceed with tonsillectomy. During the procedure tonsil was firm, gritty and adherent to tonsillar fossa. Dissection was done with difficulty. Histopathology of tonsil showed follicular hyperplasia interspersed with immature cartilage and bone cells.

DISCUSSION: Choristoma in tonsil could be a developmental abnormality of second pharyngeal arch. The surface epithelium and the lining of the tonsillar crypts of the tonsil develop from endoderm of the second pharyngeal pouch.

The mesenchymal cells that surround the crypts arise from materials of second pharyngeal arch. Developmental abnormality leading to formation of cartilage and bone within tonsil can result in osteo-cartilaginous choristoma of tonsil.

The extra-skeletal proliferation of cartilage in head and neck probably reflects the multipotential nature of primitive mesenchymal cells, which could be stimulated to grow by inflammation, trauma or irritation. The other reason could be cartilage development from heterotopic fetal cartilaginous remnants.

Cartilage choristoma in head and neck is common in oral cavity. Tongue is the usual site, followed by buccal mucosa and soft palate.1,2,3

Cartilage choristoma should be differentiated from metaplasia. Metaplasia is characterised histologically by diffuse deposits of calcium and scattered cartilaginous cells in various stages of maturation in single or clustered foci. 4,5

This patient had both bone and cartilaginous cells surrounded by normal tonsillar tissue. 


\section{REFERENCES:}

1. Modayil PC, Joseph A, Thomas I, Sulochana G, Xavier J. Choristoma of tonsil. Indian J Otolaryngol Head Neck Surg 2005 Oct-Dec; 57(4): 344-5.

2. Kannar V, Prabhakar K, Shalini SS. Cartilaginous choristoma of tonsil: A hidden clinical entity. J Oral Maxillofac Pathol 2013 May-Aug; 17 (2): 292-293.

3. Pandey H, Thakur S, Gupta MK, Patiri K. Cartilaginous Choristoma of Palatine Tonsil. Journal of Case Reports; http://www.casereports.in/articles/2/1/cartilaginous-choristoma-of-palatinetonsil. html. 10-11-2013. 13-11-2013.

4. Ashraf MJ, Azarpira N, Gandomi M. Cartilaginous Choristoma in Palatine Tonsil. IRCMJ 2010; 12 (1): 65-67.

5. Bharti JN, Ghosh N, Arora P, Goyal V. Chondroid choriostoma of palatine tonsil - a rare entity. J Clin Diagn Res 2013 Aug; 7 (8): 1700-1.

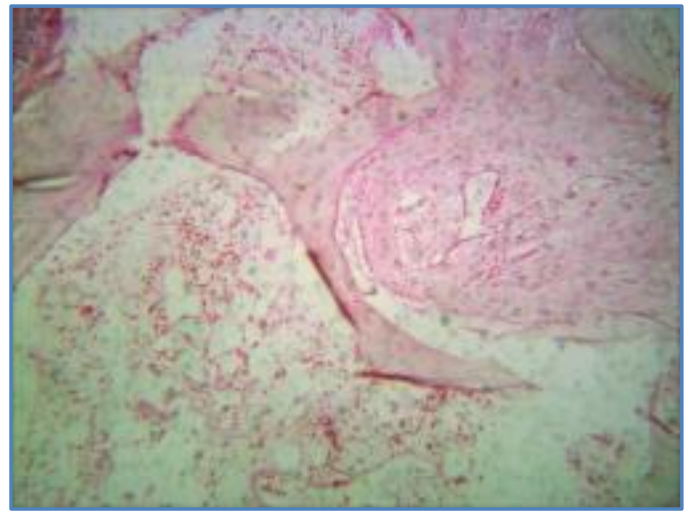

Bone

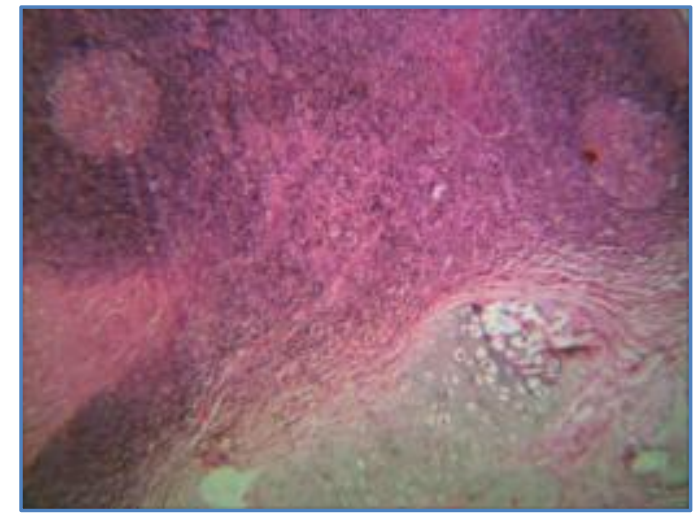

Cartilage

\section{AUTHORS:}

1. K. Shoba

2. Harikumar

3. K. Srinivasan

4. K. Deepak Raj

\section{PARTICULARS OF CONTRIBUTORS:}

1. Associate Professor, Department of ENT, Saveetha Medical College.

2. Assistant Professor, Department of ENT, Saveetha Medical College.

3. Professor, Department of ENT, Saveetha Medical College.

4. Senior Resident, Department of ENT, Saveetha Medical College.

\section{NAME ADDRESS EMAIL ID OF THE CORRESPONDING AUTHOR:}

Dr. Shoba K,

Shanthi Health Center,

Sholavarum,

Opposite to Sengalamman Koil,

Chennai-600067.

Email: shobasridhar@ymail.com

Date of Submission: 22/07/2014.

Date of Peer Review: 23/07/2014.

Date of Acceptance: 31/07/2014.

Date of Publishing: 06/08/2014. 